\title{
Review
}

\section{Potential of apoptotic pathway-targeted cancer therapeutic research: Where do we stand?}

\author{
S Baig ${ }^{*, 1,2}$, I Seevasant ${ }^{1}$, J Mohamad ${ }^{2}$, A Mukheem ${ }^{1}$, HZ Huri ${ }^{3,4}$ and T Kamarul|,1,3
}

Underneath the intricacy of every cancer lies mysterious events that impel the tumour cell and its posterity into abnormal growth and tissue invasion. Oncogenic mutations disturb the regulatory circuits responsible for the governance of versatile cellular functions, permitting tumour cells to endure deregulated proliferation, resist to proapoptotic insults, invade and erode normal tissues and above all escape apoptosis. This disruption of apoptosis has been highly implicated in various malignancies and has been exploited as an anticancer strategy. Owing to the fact that apoptosis causes minimal inflammation and damage to the tissue, apoptotic cell death-based therapy has been the centre of attraction for the development of anticancer drugs. Increased understanding of the molecular pathways underlying apoptosis has enabled scientists to establish unique approaches targeting apoptosis pathways in cancer therapeutics. In this review, we reconnoitre the two major pathways (intrinsic and extrinsic) targeted cancer therapeutics, steering toward chief modulators of these pathways, such as B-cell lymphoma 2 protein family members (pro- and antiapoptotic), inhibitor of apoptosis proteins, and the foremost thespian of extrinsic pathway regulator, tumour necrosis factor-related apoptosis-inducing agent. Together, we also will have a look from clinical perspective to address the agents (drugs) and therapeutic strategies adopted to target these specific proteins/pathways that have entered clinical trials.

Cell Death and Disease (2016) 7, e2058; doi:10.1038/cddis.2015.275; published online 14 January 2016

\section{Facts}

- Hastened findings in the field of cell death and cancer have enabled us to understand the intricate molecular machinery inside of a cell, governing complex processes like cell death, and allowed us to translate those findings into promising clinical benefits

- Apoptosis or known as programmed cell death is a physiological process that is responsible for eliminating unwanted, damaged, mutated and/or aged cells that might pose robust threat to the living body if not removed. Deregulation of this pathway (excessive or recessive) is central to various diseases, cancer being one of them

- Apoptosis is triggered as a result of various DNAdamaging agents such as ultraviolet radiations and chemotherapeutic agents. In response to such stresses, a cell can activate the DNA repair systems for the damage to be repaired; however, if the damage is irreparable it will, or continue to, survive with the oncogenic mutations resulting in aberrant functions leading to various diseases like cancer.

\section{Open Questions}

- In response to various cellular stresses, a mammalian cell is programmed to react in a number of ways. Does the nature or extent of the stress determines the type of reaction for the cell to be executed? For instance, DNA damage instigated in a cell can leave it with two choices, either to repair that damage or to instruct it to commit suicide through apoptotic pathways because the damage is irreparable. The question is who decides cell's fate or who is the decision maker? Many therapeutic agents have been proposed with robust anticancer activity capable of inducing apoptosis in cancer cells, but the mechanisms defining their mode of action remain a mystery. Further insights into that can take cancer therapeutic research in new directions

\footnotetext{
${ }^{1}$ Department of Orthopaedic Surgery, Tissue Engineering Group, Faculty of Medicine, University of Malaya, Kuala Lumpur 50603, Malaysia; ${ }^{2}$ Institute of Biological Sciences, Faculty of Science, University of Malaysia, Kuala Lumpur 50603, Malaysia; ${ }^{3}$ Clinical Investigation Centre, University of Malaya Medical Centre, Kuala Lumpur 50603, Malaysia and ${ }^{4}$ Department of Pharmacy, Faculty of Medicine, University of Malaya, Kuala Lumpur 50603, Malaysia

${ }^{*}$ Corresponding author: S Baig or T Kamarul, Department of Orthopaedic Surgery, University of Malaya, Tissue Engineering Group, Faculty of Medicine, Kuala Lumpur 50603 , Malaysia. Tel: +60 37967 7022; Fax: +60 37949 4642; E-mail: s.baig@um.edu.my (SB) or Tel: +60 37949 2061; Fax: +60 37949 4642; E-mail: tkzrea@um.edu.my (TK) Abbreviations: BCL-2, B-cell lymphoma 2; IAPs, inhibitor of apoptosis proteins; TRAIL, tumour necrosis factor-related apoptosis-inducing ligand; DRs, death receptors; $\mathrm{DD}$, death domain; DISC, death-inducing signalling complex; c-FLIP, cellular FLICE inhibiting proteins; BID, BH3 interacting-domain death agonist protein; BAD, Bcl-2associated death promoter protein; BAX, BCL-2-associated X protein; BIK, BCL-2-interacting killer protein; BCL-xL, B-cell lymphoma-extra-large protein; BH3-only proteins, $\mathrm{BCL}-2$ homology 3 only proteins; cIAP, cellular inhibitor of apoptosis protein; BFL-1, BLC-2-related protein A1; MCL-1, induced myeloid leukaemia cell differentiation protein; PUMA, p53 upregulated controller of apoptosis; NAIP, neural inhibitory apoptosis protein; XIAP, X-linked inhibitor of apoptosis protein; MOMP, mitochondrial outer membrane potential; AML, acute myeloid leukaemia; CLL, chronic lymphocytic lymphoma; NHL, non-Hodgkin's lymphoma; HDACs, histone deacetylases; HDACi, histone deacetylases inhibitors; CTCL, cutaneous T-cell lymphoma

Received 02.4.15; revised 17.7.15; accepted 25.8.15; Edited by M Agostini
} 
- Despite all the efforts that have been made to combat cancer we still cannot claim victory over cancer. And this really questions our research directions that have been undertaken. Are we really heading in right direction to win this battle against cancer?

Cell death is essential for life. ${ }^{1}$ Cell death plays critical roles in regulating embryonic development, maintaining tissue homoeostasis, controlling immune function, tumour suppression and infection resistance..$^{2-4}$ Cell death eliminates unfit cells from the body. ${ }^{5}$ Throughout life, cell death must balance cell proliferation. $^{3}$ Cell death is responsible for an array of dispensable physiological processes, including removal of useless cells from the immune system, ${ }^{6}$ duct formation in mammary glands, thymus degeneration with ageing and finally elimination of infected cells to limit pathogen spread. ${ }^{7}$ It also aids in shaping immune repertoire and refines immune responses. ${ }^{4,8}$ The process responsible for execution of all of the above-mentioned events is called apoptosis. Apoptosis is perhaps the best-studied form of programmed cell death that forces the demise of useless or worn out cells. The goodness of apoptosis lies in the fact that they principally engage in dismissal of damaged or stressed cells in a fashion that is expected to cause the slightest damage and inflammation. ${ }^{1,9,10}$

Apoptotic cell death is generally characterized by a morphologically homogeneous entity. ${ }^{11}$ The chief morphological feature of apoptosis is shrinkage of nuclei, nuclear chromatin condensation, cytoplasmic shrinkage, dilated endoplasmic reticulum and membrane blebbing. ${ }^{12}$ The contents of the cell become swathed in 'apoptotic bodies' which are then recognized and engulfed by nearby phagocytic cells and digested in lysosomes. ${ }^{13}$ Other forms of cell death, such as necrosis and necroptosis, have been recognized and studied; ${ }^{12,14}$ however, they are not addressed in this review. The fact that cell death is a genetically controlled process has allowed developments in exploring the machineries of many different diseases and has facilitated the development of pharmacological agents that initiate this cell death.

Most of what we know about apoptosis has been developed in the past few decades. These studies have unrevealed multifaceted apoptotic mechanisms that are interleaved with other significant pathways, such as cell cycle, cellular metabolic and receptor transduction pathways. ${ }^{1}$ In this review, we will highlight the apoptotic pathways that have been targeted by researchers for potential anticancer drug development and will discuss the current status of cell deathtargeted cancer therapeutics.

\section{Major Signalling Pathways that Mediate Apoptosis: Distinct but Congregating}

Apoptosis is triggered by chronological activation of caspase family via two distinct but congregating pathways known as intrinsic and extrinsic pathways. ${ }^{15,16}$ The intrinsic pathway (commonly known as 'stress' or 'mitochondrial' pathway) is dominantly controlled by $\mathrm{Bcl}-2$ protein family. This mitochondria-controlled cell death is a two-step process. At first, numerous stimuli trigger an increase in mitochondrial permeability, which results in release of apoptogenic factors through the outer membrane and disturbs the electrochemical gradient of inner membrane. This entire havoc is sensed by a multiprotein complex called mitochondrial permeability transition that resides at the junction of inner and outer mitochondrial membranes. ${ }^{17}$ Secondly, this mitochondrial dysfunction concludes in the disturbance of plasma membrane integrity (necrosis) and/or the activation of specific apoptogenic proteases (caspases) by mitochondrial proteins leak into the cytosol (cytochrome $c$-apoptosis-inducing factor) with activation of apoptosis. ${ }^{18}$ To execute apoptosis, this released cytochrome $c$ requires assembling a complex called 'apoptosome' (a multiprotein caspase activating complex). Upon formation of the apoptosome complex, the key constituent of apoptosome called apoptotic protease activating factor 1 binds procaspase 9 via interface with its caspase recruitment domain ${ }^{19}$ and executes apoptosis. This intrinsic pathway could be initiated in response to various stresses, including DNA-damaging agents, activation of oncogenes, overload of $\mathrm{Ca}^{2+}$, deprivation of growth factors, oxidants and microtubule-targeted drugs (please refer to Figure 1). ${ }^{20}$ The mitochondrial dysfunctional consequences, such as loss of inner mitochondrial membrane potential, hyper production of superoxide ions, disturbance in mitochondrial biogenesis, outflow of matrix calcium glutathione and release of membrane proteins, ${ }^{21,22}$ hold promising potential for cancer therapeutic strategies via induction of apoptosis in cancer cells which is discussed later in this review.

This mitochondrial pathway is highly controlled by BCL-2 family members that act by stimulating $\mathrm{BH}$-only family proteins which activates proapoptotic effectors BAX and BAK. These proapoptotic effectors disrupt the mitochondrial membrane that ensues in the release of cytochrome $c$ that forms a complex 'apoptosome'. This complex consists of caspase-9, Apaf-1 and cytochrome $c$ which activates effector caspases and executes apoptosis. The released protein second mitochondria-derived activator of caspases (SMAC) blocks the caspase inhibitor called X-linked inhibitor of apoptosis protein (XIAP). On the other hand, extrinsic/death receptor-mediated apoptosis is engaged when certain death receptor ligands, such as FAS ligand and TNF, tie up their death receptors with the plasma membrane, thereby activating caspases- 8 via FADD and TRADD. These two pathways congregate at the effector caspases (caspase-3, -6 and -7). Generation of tBID by caspase- 8 in death mediated pathway could engage intrinsic pathway and magnify the apoptotic response.

Alternatively, activation of these caspases is also brought about by the formation of death receptor (DR) signalling, initiated by DRs at the cellular surface. ${ }^{23-25}$ Initiation and execution of apoptosis via this pathway is referred to as 'extrinsic' or 'death receptor' pathway. All the members of DRs are expressed on the cell membrane and are characterized by the presence of a death domain (DD) that plays a crucial role in apoptotic signal transduction. ${ }^{26}$ So far, six members of DR family have been recognized: TNF-R1, CD95 (APO1/FAS), DR3, TRAIL-R1, TRAIL-R2 and DR6, ${ }^{25,26}$ TRAIL receptors (TRAIL-R1 and TRAIL-R2) are promising targets for cancer therapy. ${ }^{27-30}$ This extrinsic apoptotic cell is introduced by signals originating from these 


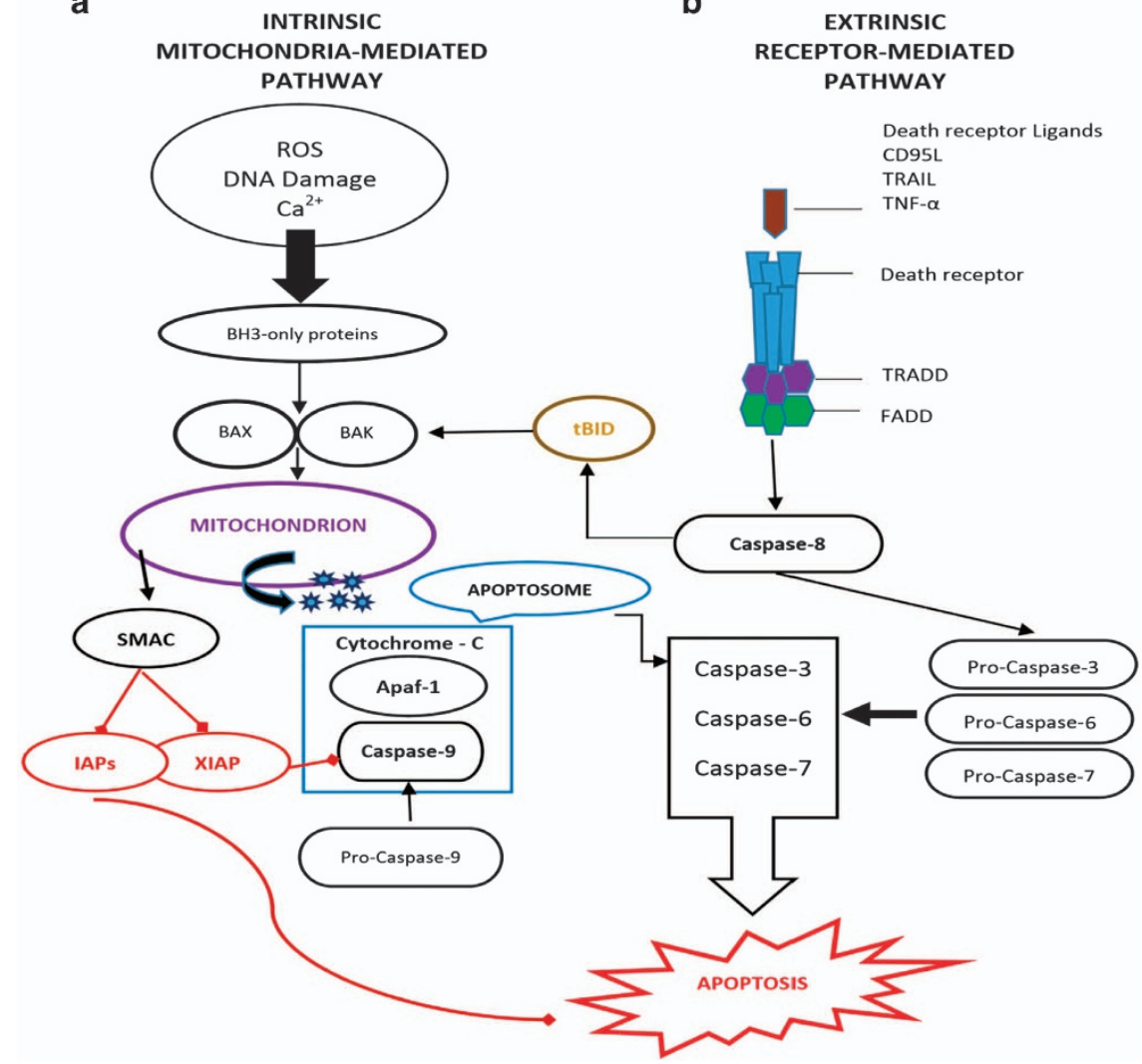

Figure 1 The mitochondria-mediated intrinsic (a) and death receptor-mediated extrinsic (b) pathway. Apaf-1, apoptotic protease activating factor 1; FADD, Fas-associated death domain; TRADD, TNFR-associated death domain protein

cell-surface DRs activated by death ligands. ${ }^{23,31}$ This triggering of DRs by death ligands ensues in the formation of a death-inducing signalling complex (DISC). ${ }^{23,32}$ This DISC consists of oligomerized receptors: the DD containing adaptor molecule called Fas-associated death domain, procaspase-8 (FLICE), procaspase-10 and the cellular FLICE inhibitory proteins (c-FLIP) ${ }^{33}$ (Figure 1). Formation of DISC activates procaspase-8/10 and subsequently initiates proapoptotic cascade of caspases. ${ }^{34}$

\section{Carcinogenesis and Apoptosis - Molecular Targeted Therapies}

One of the prominent hallmarks of cancer is evasion of apoptosis by cancer cells. ${ }^{35}$ Because inhibition of apoptosis lies at the heart of all tumour development, tumour cell death is required for the clearance of malignant cells and maintenance of definite number of healthy cells. ${ }^{36}$ Targeting cellular death pathways presents some potential targets for therapeutic intervention in all cancers. ${ }^{37,38}$ The most obvious strategy for cancer therapy is to target the lesions that suppress cell death - specifically apoptosis in tumour cells. The proapoptotic effects inflicted by growth-deregulating mutations suggest that tumours depend upon the antiapoptotic factors to sustain growth. In this section, we will concentrate on the pro- and antiapoptotic proteins of BCL-2 protein family (BCL-2, BCL-xL,
BCL-w, Mcl-1 and BH3-only proteins along with inhibitor of apoptosis proteins (IAPs) that have been targeted for therapeutic intervention.

Intrinsic Pathway-Targeted Therapeutic Strategies BCL-2 Protein Family: An Introductory visit to the Family and their Therapeutic Targets

In pathological as well as physiological settings, transgenic and gene-targeted mice studies have established the function of various BCL-2 protein family members. Hence, it has been established that these proteins govern the survival of all the cells and increased expression of these antiapoptotic proteins is involved in development and progression of many tumours. ${ }^{39}$

Hitherto, there are a total of 25 known genes of BCL-2 protein family. ${ }^{40}$ These proteins dictate the cell in making cell survival/death decisions by governing mitochondrial outer membrane permeabilization (MOMP). ${ }^{40-43}$ Members of this family are characterized by four conserved amphipathic $a$-helical regions designated BCL-2 homology $(\mathrm{BH})$ 1-4 domains. ${ }^{44}$ Based on these domains, members of this family could broadly be categorized into three subgroups: (1) proapoptotic (multidomain) proteins BAX and BAK, (2) antiapoptotic (multidomain) proteins (BCL-2, BCL- $x \mathrm{~L}$, BCL-w, Bfl-1 and Mcl-1) and (3) proapoptotic (single domain) 
BH3-only proteins BID, BIM, BAD, p53 upregulated controller of apoptosis (PUMA) and NOXA (refer to Table 1). BH3-only proteins play a key role in regulating and promoting apoptosis and thus serve as an appealing target for therapeutic intervention. ${ }^{44-48}$

These prosurvival BCL-2 protein family members have been shown to render many cell types resistant to diverse apoptotic stimuli. ${ }^{49,50}$ Interfaces between the members of the BCL-2 protein family via the $\mathrm{BH} 3$ unit play a critical role in regulating cell death and are central to apoptosis. ${ }^{41}$ BCL-2 overexpression has been found in various haematological and solid tumours, such as acute myeloid leukaemia (AML), chronic lymphocytic leukaemia (CLL), non-Hodgkin's lymphoma (NHL), myeloma, lung, breast, prostate, melanoma, hepatocellular carcinoma. ${ }^{41}$ Moreover, it is over-expressed as a result of $\mathrm{t}(14 ; 18)$ chromosomal translocation in approximately $90 \%$ of follicular centre B-cell lymphomas. ${ }^{3,51}$ Strategies that have been employed to overcome the cyto-protective effects of these antiapoptotic members include: (1) interference with mRNA function, (2) development of smallmolecule drugs to target specific proteins, and (3) shut down of gene transcription. In addition to their direct role in preventing apoptotic cell death, they also act by blocking the proapoptotic proteins. For example, proapoptotic protein Bak is normally sequestered by $\mathrm{Mcl}-1$ and $\mathrm{Bcl}-x \mathrm{LL} .{ }^{52}$ Only when Bak is released from both $\mathrm{Mcl}-1$ and $\mathrm{Bcl}-\mathrm{xL}$ can it induce apoptosis.

\section{Antisense Oligonucleotides - Targeting the mRNA}

Antisense oligonucleotides (ASOs) are short synthetic sequences of single-stranded DNA that can bind to target mRNA, ensuing inhibition of mRNA by RNase $\mathrm{H}$ (ubiquitous endonuclease). These ASOs function by enhancing sensitivity to cytotoxic drugs in vitro and xenograft models. Although, synthesis of these phosphodiester oligonucleotides is not complex matter, ${ }^{53}$ their use has been limited owing to the fact that are rapidly degraded by intracellular endonucleases and exonucleases. ${ }^{53-56}$ Advancements in the development of ASOs now offer new generation ASOs with higher target affinity and stability that are being tested in clinical fashion. ${ }^{57,58}$ Oblimersen sodium (G3139, Genasense), an 18-base antisense phosphorothioate oligonucleotide, is a potential anti-BCL-2 mRNA agent that has advanced in clinical settings. ${ }^{40,41}$ It is the most promising inhibitor of antiapoptotic protein BCL-2 protein that has been studied for the treatment of lymphoma and is in clinical trials. ${ }^{59}$ It has also been tested in combination with other anticancer agents in various cancer types, such as multiple myeloma, small-cell lung cancer ${ }^{60}$ AML, ${ }^{61}$ melanoma and non-Hodgkin's lymphoma. ${ }^{62}$ Status of oblimersen in clinical settings is presented in Table 2 .

$B C L-x S$, structurally similar to $B C L-x L$, is another antiapoptotic member. Strategies to sensitize tumour cells to chemotherapy in vitro using ASOs have been adopted to

Table 1 BCL-2 protein family members and their function

\begin{tabular}{|c|c|c|c|c|}
\hline BCL-2 family member & BH domain & Proapoptotic & Antiapoptotic & Proapoptotic function type \\
\hline $\begin{array}{l}\text { BCL-2 } \\
\text { BCL-xL } \\
\text { BCL-w } \\
\text { BFL-1 } \\
\text { MCL-1 } \\
\text { BAX } \\
\text { BAK } \\
\text { BIM } \\
\text { BID } \\
\text { BAD } \\
\text { BIK } \\
\text { NOXA } \\
\text { PUMA }\end{array}$ & $\begin{array}{l}\mathrm{BH} 1-4 \\
\mathrm{BH} 1-4 \\
\mathrm{BH} 1-4 \\
\mathrm{BH} 1-4 \\
\mathrm{BH} 1-4 \\
\mathrm{BH} 1-3 \\
\mathrm{BH} 1-3 \\
\text { BH3-only } \\
\text { BH3-only } \\
\text { BH3-only } \\
\text { BH3-only } \\
\text { BH3-only } \\
\text { BH3-only }\end{array}$ & $\begin{array}{l}\sqrt{ } \\
\sqrt[V]{ } \\
\sqrt[V]{ } \\
\sqrt[V]{ } \\
\sqrt{ } \\
\sqrt[V]{ } \\
\sqrt[V]{ } \\
\sqrt[V]{ }\end{array}$ & $\begin{array}{l}\sqrt{ } \\
\sqrt{ } \\
\sqrt[V]{ } \\
\sqrt[V]{ } \\
\sqrt[V]{ }\end{array}$ & $\begin{array}{l}\text { None } \\
\text { None } \\
\text { None } \\
\text { None } \\
\text { None } \\
\text { Effector } \\
\text { Effector } \\
\text { Activator } \\
\text { Activator } \\
\text { Sensitizer } \\
\text { Sensitizer } \\
\text { Sensitizer } \\
\text { Sensitizer }\end{array}$ \\
\hline
\end{tabular}

Table 2 Published clinical data of Oblimersen (an antisense oligonucleotide)

\begin{tabular}{|c|c|c|c|}
\hline Regimen & Disease type & Phase & Reference \\
\hline Oblimersen & Advanced solid cancer and CLL & | and || & 105,129 \\
\hline Oblimersen with rhitoximub & NHL & II & 105,130 \\
\hline Oblimersen with mitoxantrone & CRPC & I & 105,131 \\
\hline Oblimersen with docetaxel & CRPC and breast cancer & II and I & 132,133 \\
\hline Oblimersen with docetaxel & NSCLC or SCLC & III & 40 \\
\hline Oblimersen with docetaxel & HRPCa (EORTC) & II & 132 \\
\hline Oblimersen with danorubicin and cytarabine & AML & I & 134 \\
\hline Oblimersen with carboplatin and etoposide & SCLC & | and || & 60,135 \\
\hline Oblimersen with decarbazine & Melanoma & III & 62 \\
\hline Oblimersen with dexamethasone & Advanced MM & III & 136 \\
\hline Oblimersen with fludarabine and cyclophosphamide & CLL & III & 137 \\
\hline Oblimersen with gemtuzumab and ozogamicin & AML & II & 138 \\
\hline
\end{tabular}

Abbreviations: CLL, chronic lymphocytic leukaemia; NHL, non-Hodgkin's lymphoma; CRPC, castration-resistant prostate cancer; SCLC, small-cell lung carcinoma; NSCLC, non-small-cell lung carcinoma; MM, multiple myeloma; AML, acute myeloid leukaemia 
promote BCL-xS production. Improved efficacy of cisplatin has also been reported when used with antisense $B C L-x L$ oligonucleotide ${ }^{63}$ in mesothelioma cells.

MCL-1 is another widely expressed member of the family in various haematological malignancies and solid tumours. A number of reports have endorsed its oncogenic nature. ${ }^{64,65} \mathrm{Mcl}-1$ ASO down-regulation of MCL-1 has been identified as a potential target. MCL-1 ASO down-regulated MCL-1 significantly and synergized with 'imatinib' in inhibiting growth of CML cells. ${ }^{41}$

Oblimersen is the first oligonucleotide to demonstrate proof of principle of an antisense effect in human tumours by the documented down-regulation of the target bcl-2 protein. Oblimersen provides biologically relevant plasma levels, down-regulates target bcl-2 protein within 3-5 days of initiating treatment and yields an acceptable safety profile. ${ }^{66}$

\section{Small-Molecule Inhibitors of BCL-2 Family: Regulation of Gene Expression and Interaction with Prosurvivals Histone Deacetylase Inhibitors: Regulators of Gene Expression}

Histone deacetylases (HDACs) are critical controllers of gene expression. ${ }^{67,68}$ They act by enzymatically removing the acetyl group from histones. ${ }^{69}$ Over-expression of HDACs has been established in various critical events of tumorigenesis, such as epigenetic repression of CDKN1A (encoding the cyclin-dependent kinase inhibitor p21) tumour suppressor gene and key genes, like breast cancer 1 , early onset BRCA1 and ataxia telangiectasia and $\mathrm{Rad} 3$ related (ATR). ${ }^{67,68}$ Hence, HDACs are an attractive drug targets in oncology and

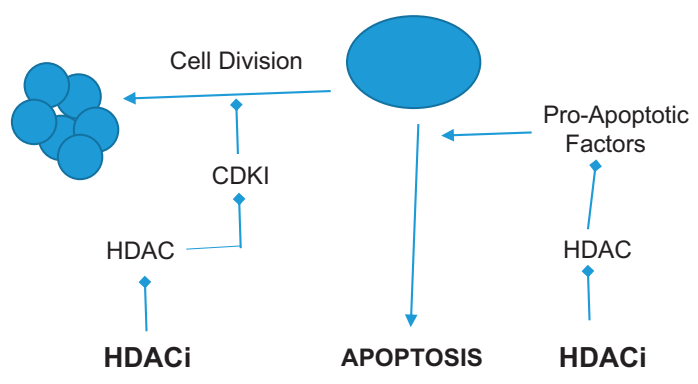

Figure 2 Schematic presentation of the role of $\mathrm{HDACi}$ inflammation. ${ }^{70}$ Genetic knock-down of HDACs has been shown to induce apoptosis and cell cycle arrest in a variety of tumour types, such as colon, lung, breast and acute promyelocytic leukaemia, highlighting HDAC activity as a key indicator of survival and tumorigenic capacity. ${ }^{71}$

The effects of HDAC inhibitors on tumour cells include induction of tumour cell death, cell cycle arrest, senescence, differentiation, autophagy and increased tumour immunogenicity (Figure 2). The most common and the widely studied antitumor effect of HDAC inhibitors is apoptotic cell death. ${ }^{72,73}$ Butyrate was the first HDAC inhibitor identified as potential anticancer therapy which was based on its ability to induce differentiation, which supports the basis that induction of differentiation of transformed cells contributes to anticancer therapies. A vast array of both natural and synthetic compounds acts as HDAC inhibitors. ${ }^{71}$ Two histone deacetylases inhibitors (HDACi), vorinostat and romidepsin, have been approved by FDA for the treatment against refractory cutaneous T-cell lymphoma (CTCL). Many HDACi have entered phase I to III clinical trials (refer to Table 3 for the list of currently being tested HDACi in clinical settings). More than 350 clinical trials have been completed or are underway using HDAC inhibitors, both as single agents or in combination, for the treatment of malignancies, including haematological malignancies. ${ }^{123,124}$ The most successful combination therapy is the rationally designed combination of HDAC inhibition and proteasome inhibition. ${ }^{125}$ Two phase II clinical trials have been conducted with vorinostat and bortezomib for relapsing or refractory multiple myeloma with a response rate of 42 and $27 \%$, respectively. ${ }^{126,127}$ Another combination of vorinostat and marizomib in patients with melanoma. Despite of all the efforts that have been made for the development of HDACi, the target specificity of HDACi and the requirement for target and site selective activity to inhibit HDACs to achieve therapeutic efficacy have hindered the efforts to develop HDACi and remain a debatable issue. Another promising approach in anticancer therapy is the combination of HDAC inhibition and hormone therapy. A phase II clinical trial of vorinostat and tamoxifen was carried-out in hormone-resistant breast cancer patients with a response rate of $19 \%$. To date, three HDAC inhibitors have been approved by the FDA for the treatments of CTCL (vorinostat (SAHA) and romidepsin (Istodax)) and peripheral T-cell lymphoma (belinostat (Beleodaq) and romidepsin), ${ }^{128}$ and are being further evaluated for their potential

Table 3 List of HDAC inhibitors in clinical settings

\begin{tabular}{|c|c|c|c|}
\hline Agent & Cancer type & Trial phase & Reference \\
\hline CHR-3996 & Refractory solid tumours & I & 164 \\
\hline Belinostat (PXD101) & Relapsed or refractory & II & 165 \\
\hline Practinostat (SB939) & Refractory solid tumours in paediatric patients & I & 166 \\
\hline Practinostat (SB939) + Erlotinib & Advanced aero-digestive tract tumour & i & 167 \\
\hline Entinostat (MS275) + 13-cis retinoic acid & Solid tumours & l & 168 \\
\hline Chidamine (CS055/HBI-8000) & Solid tumours and lymphomas & II & 169 \\
\hline Girinostat (ITF2357) & Relapsed or progressive multiple myeloma & II & 170 \\
\hline Quisinostat (JNJ-26481585) & Advanced solid tumours & I & 171 \\
\hline Panobinostat (LBH589) & Relapsed or refractory NHL and advanced solid tumours & | and || & 172,173 \\
\hline Panobinostat (LBH589) + melphalan & Relapsed or refractory multiple myeloma & | and || & 174 \\
\hline Panobinostat (LBH589) + imatinib & Treatment-refractory metastatic gastrointestinal stromal tumours & I & 175 \\
\hline
\end{tabular}

Abbreviations: SCLC, small-cell lung carcinoma; FL, follicular lymphoma ${ }^{176-179}$ 
as anticancer agents - alone and in combination, in haematological malignancies and solid tumours. Table 3 represents a list of HDAC inhibitors in clinical settings.

Aberrant DNA methylation that silences the expression of tumour suppressor genes occurs recurrently in patients with $\mathrm{AML}$, and an attractive target in $\mathrm{AML}$ is the histone methyltransferase EZH2. ${ }^{74}$ Trichostatin-A - an HDACi in combination with 5-AZA-CdR and DZNep - has been shown to induce a remarkable synergistic antineoplastic effect against human AML cells. ${ }^{74}$ Cytarabine (Ara-C) has been a major drug for $A M L$ treatment for more than three decades. ${ }^{75}$ Trichostatin-A - an HDACi in combination with 5-AZA-CdR and DZNep - has been shown to induce a remarkable synergistic antineoplastic effect against human AML cells. ${ }^{74}$ Another HDACi (valproic acid) has been shown to exhibit very promising synergism when used in combination with decitabine in AML. ${ }^{76}$ Vorinostat along with ACY-1215 and Belinostat are potent HDACi with a hydroxamic acid moiety targeting class I and II HDACs that has shown modest activity in multiple myelomas. ${ }^{77}$ Vorinostat was the first of the HDACi to be approved for clinical use in the therapy of CTCL; however, more recently, romidepsin received FDA approval for the therapy of CTCL. ${ }^{78}$ For the treatment of NHL, Givinostat - an orally administrated hydroxamate - is being investigated in a clinical trial. ${ }^{79}$ However, it has been demonstrated in a preclinical study that an intact host immune system is essential for the efficacy of HDAC inhibitors (148p) based on the evidence that immunodeficient patients would be less responsive to HDAC inhibitors ( $p)$.

\section{BH3 Mimetics - Misleading the Prosurvivals}

There is a common agreement that BH3-only proteins are indispensable originators of apoptosis that promulgate intrinsic and extrinsic apoptotic cell death pathways. Proapoptotic members of the BCL-2 protein family (please refer to Table 1) could be further classified based on the blocks of sequence homology called $\mathrm{BH}$ domains. All BH3-only proteins contain only one domain in common called a-helical $\mathrm{BH} 3$ domain. ${ }^{10}$ This conserved $\mathrm{BH} 3$ domain has been demonstrated to play a crucial role in cancer therapy. ${ }^{80-82}$ This pathway is triggered by three subgroups of $B C L-2$ protein family: BH3 (BCL-2 homology 3)-only proteins, BCL-2, BCL-2-associated $X$ protein (BAX) and BCL-2 antagonist/killer (BAK), which interact with each other on the mitochondrial outer membrane. BH3-only proteins serve by transmission of signals to initiate apoptosis, BH3-only proteins induced either transcriptionally or post translationally by cytotoxic stress have been shown to carry out their purpose by two mechanisms. ${ }^{48,83-85}$ They act either by neutralizing antiapoptotic BCL-2 protein family ${ }^{52,86,87}$ or by directly activating BAK and BAX. ${ }^{47,88-90}$ Former mode of action has been well understood both structurally and functionally and thus has been the target for drug development. They antagonize the antiapoptotic BCL-2 protein family members by binding their hydrophobic groove by the insertion of four hydrophobic residues. ${ }^{91-93}$ Members such as BCL-2 antagonist of cell death (BAD) and NOXA are selective in binding with its antiapoptotic siblings, whereas other BH3-only proteins, such as BIM, tBID and PUMA, neutralize all the other antiapoptotic siblings. ${ }^{86,88}$

Many small-molecules BH3-mimicking agents, both natural and synthetic, have been developed ${ }^{94-98}$ (please refer to Table 4 for a list of BH3-mimicking agents). Owing to the fact that antiapoptotic BCL-2 protein family members have been successfully antagonized, the potential of these $\mathrm{BH} 3$ mimetic holds considerable appeal. These $\mathrm{BH} 3$ mimetic have been adequately demonstrated by $\mathrm{ABT}-737^{99,100}$ A list of $\mathrm{BH} 3$ mimetics, some of which entered clinical trials, is given in Table 4.

\section{Inhibitors of Apoptosis Proteins}

The IAPs are the only known endogenous proteins that control the activity of both initiator and effector caspases. Controlled expression of the IAPs has been shown to influence cell death $^{101}$ and is believed to have important consequences with respect to human cancer. Over-expression of IAPs is associated with poor prognosis and chemo-resistance in several cancers. ${ }^{102-104}$ IAPs are a family of proteins that serve as endogenous inhibitors of apoptosis. ${ }^{105}$ All these have a common domain of 70 amino-acid baculo-virus repeats (BIR) that suppress caspase function by facilitating protein-protein interactions. This allows IAPs to bind to caspases, thereby inhibiting cell death. Based on the first interrogation of the mechanism of IAPs in the laboratory of John Reeds, ${ }^{106}$ XIAP was found to prevent caspase-3 processing in response to caspase-8 activation, thereby inhibit the extrinsic apoptotic signalling by blocking the activity of the downstream effector caspases, as opposed to interfering directly with caspase-8 activation. ${ }^{107}$ In addition, ClAP1 and clAP2 have also been demonstrated to antagonize caspase activity when coexpressed in yeast. ${ }^{108}$ To serve this, small-molecule inhibitors of apoptosis have been developed that act by binding to the BIR2 or BIR3 domain of XIAP, cellular inhibitor of apoptosis protein (ClAP1) and clAP2, thereby enhancing apoptosis. The human IAP family consists of eight members: NAIP, XIAP, cIAP1, cIAP2, ILP2, survivin, livin and BRUCE. ${ }^{109}$

Table 4 Clinical studies of $\mathrm{BH} 3$ mimetic as anticancer drugs

\begin{tabular}{|c|c|c|c|c|}
\hline Agents & Nature of the agent & Disease type & Phase & Reference \\
\hline $\begin{array}{l}\text { Obatoclax } \\
\text { Gossypol } \\
\text { ABT-263 } \\
\text { ABT-199 }\end{array}$ & $\begin{array}{l}\text { BH3 mimetic } \\
\text { BH3 mimetic } \\
\text { BH3 mimetic } \\
\text { BH3 mimetic }\end{array}$ & $\begin{array}{l}\text { SCLC and myelofibrosis } \\
\text { Metastic breast cancer and CRPC } \\
\text { Advanced haematological cancers } \\
\text { CLL }\end{array}$ & I and II & $\begin{array}{c}139,140 \\
141-143 \\
144 \\
145\end{array}$ \\
\hline
\end{tabular}

Abbreviations: SCLC, small-cell lung cancer; CRPC, castration-resistant prostate cancer; CLL, chronic lymphocytic leukaemia 
A variety of cancer cell lines and primary tumour biopsy samples show elevated IAP expression levels, including AML, ${ }^{108}$ renal cell carcinoma ${ }^{110}$ but not in non-small-cell lung carcinoma ${ }^{111,112}$ or cervical carcinoma. ${ }^{113}$ High expression of XIAP or clAP2 is associated with shorter overall survival, and lower complete response rates for AML. ${ }^{108}$ XIAP has also been identified as part of the progression signature in ovarian carcinoma ${ }^{114}$ and prostate cancer. ${ }^{115}$

IAPs have been highly exploited to be targeted in anticancer therapeutics and have been proved to be a good addition to the list of apoptosis-inducing strategies. ${ }^{116}$ Small-molecule inhibitors act either by targeting IAPs by mimicking SMAC (inhibitor of IAPs) or by antisense-mediated interference of XIAP mRNA and protein expression. ${ }^{105}$ Refer to Table 5 for the list of IAPs in clinical settings against cancer.

\section{Extrinsic Cell Death - the DR Pathway}

Tumour necrosis factor-related apoptosis-inducing ligand (TRAIL/Apo2L) is a member of TNF family that selectively kills a diverse range of cancer cells. The members of DR family are the key players responsible for the activation of extrinsic apoptotic pathway. ${ }^{117}$ These members are characterized by the presence of almost 80 amino-acid long motif, termed death domain. CD95 (Fas/APO1), DR3, DR6, TNF-R1, TRAIL Receptor 1 (TRAIL-R1) and TRAIL-R2 are the major DRs. TRAIL has been shown to induce apoptosis in cancer cells via its two major cell DRs TRAIL-R1 and TRAIL-R2. ${ }^{105}$ Further, these have been specifically shown to be expressed at higher levels in solid tumours. ${ }^{118}$

Owing to its disparity toxicity for transformed as opposed to normal cells, Apo2L/TRAIL shows promise as a potential cancer therapy agent. ${ }^{119}$ TRAIL is probably a good candidate in cancer therapeutics. ${ }^{118,120}$ Owing to the ability of TRAIL receptors of inducing cell death specifically in cancer cells, agonistic antibodies against TRAIL receptors have been developed and demonstrated to trigger apoptosis in a number of cancer cells. ${ }^{121}$ Despite all the success of TRAIL targeted cancer therapy, TRAIL resistance is a common impediment in TRAIL-based therapy that limits the efficacy of these drugs. ${ }^{122}$ Refer to Table 6 for a list of drugs targeting DRs in clinical settings.

\section{Conclusion}

Most of what we know about apoptosis has been developed and understood only recently. In depth evaluation and assessment of this intricate machinery (cell) running inside of our bodies performing various functions has enabled us to unravel probably a bit of what is not known yet. The core idea of designing therapeutic drugs for cancer is based on the fact that worn out or damaged cells commit suicide in order for the body to continue to grow normally, maintaining a healthy number of cells, whereas this phenomenon is greatly disturbed in cancer cells. Identification of the key players involved in the execution of apoptosis and their interaction with other significant participants of apoptosis has boosted some of the significant developments made in the field of cancer therapeutics.

Apoptosis-targeted cancer therapy has been an indispensable approach in combating this deadly disease cancer; however, we are still left with huge challenges to be overcome. Development of drugs that act either by blocking the action of antiapoptotic proteins, such as IAPs, small-molecule inhibitors (antisense oligonucleotides), or by halting, hampering or interference with the transcription of RNA, such as small interfering RNA, BH3 mimetic and some HDACi, holds robust potential for use in cancer therapy; however, the hope to cure cancer is yet to be seen.

Table 5 List of IAPs for the treatment of various malignancies

\begin{tabular}{|c|c|c|c|c|}
\hline Agents & Target disease & Target & Phase & Reference \\
\hline $\begin{array}{l}\text { SH-130 } \\
\text { JP-1201 } \\
\text { SH-122 } \\
\text { AEG35156 } \\
\text { YM155 } \\
\text { LY2181308 }\end{array}$ & $\begin{array}{l}\text { Prostate cancer cell line } \\
\text { Pancreatic cancer cell line } \\
\text { Prostate cancer cell line } \\
\text { Advanced solid cancers } \\
\text { Advanced solid cancers } \\
\text { CRC cell lines }\end{array}$ & $\begin{array}{l}\text { IAPS } \\
\text { IAPS } \\
\text { IAPS } \\
\text { XIAP } \\
\text { Survivin } \\
\text { Survivin }\end{array}$ & $\begin{array}{c}- \\
- \\
- \\
\text { II } \\
\text { I and II } \\
\text { Preclinical }\end{array}$ & $\begin{array}{c}146 \\
147 \\
148 \\
149,150 \\
151 \\
152\end{array}$ \\
\hline
\end{tabular}

Abbreviations: CRC, colorectal cancer cell line; IAPs, inhibitor of apoptosis proteins

Table 6 Clinical status of agonists targeting death receptors (extrinsic pathway)

\begin{tabular}{|c|c|c|c|}
\hline Agonist & Target & Phase & Reference \\
\hline $\begin{array}{l}\text { Dulanermin } \\
\text { Monoclonal antibodies }\end{array}$ & $\begin{array}{l}\text { CRC and NSCLC } \\
\text { DR agonists }\end{array}$ & I and II & 153,154 \\
\hline Mapatumumab & Advanced solid tumours, and NSCLC & | and || & $155-157$ \\
\hline CS-1008 & Advanced solid tumours & I & 158 \\
\hline PR095780 & Advanced solid tumours, NHL & | and || & 159 \\
\hline Lexatumumab (HGS-ETR2) & Advanced solid tumours & I & 160,161 \\
\hline Conatumumab (AMG-655) & Advanced solid tumours & I & 162,163 \\
\hline
\end{tabular}

Abbreviations: CRC, colorectal cancer; NSCLC, non-small-cell lung carcinoma; NHL, non-Hodgkin's lymphoma 
There is no qualm in the fact that our understanding of mechanistic pathways and their interaction with others has advanced considerably in last 20 years, but the fact that we have not been able to demonstrate our win in the battle against cancer questions our current strategies adopted to address cancer in near future. Responses to DNA damage have been shown to play crucial roles in responding against stresses that stimulate abnormal functions or cause DNA damage. Manipulation of this already existing mechanism could prove to be an interesting target in cancer therapeutics, owing to the fact that the major decisions of cell survival and death are decided by that response system.

\section{Conflict of Interest}

The authors declare no conflict of interest.

Acknowledgement. This study was supported by Post Graduate Research Grant-PG075-2013B, RP024A-14HTM and HIR-MoE grant (reference no. UM.C/ 625/1/HIR/MOHE/CHAN/03, A/C no. A000003-50001).

1. Walsh CM. Grand challenges in cell death and survival: apoptosis vs. necroptosis. Front Cell Dev Biol 2014; 2: 3.

2. Adams J, Cory S. The Bcl-2 apoptotic switch in cancer development and therapy. Oncogene 2007; 26: 1324-1337.

3. Czabotar PE, Lessene G, Strasser A, Adams JM. Control of apoptosis by the BCL-2 protein family: implications for physiology and therapy. Nat Rev Mol Cell Biol 2014; 15 : 49-63.

4. Adams JM, Cory S. Bcl-2-regulated apoptosis: mechanism and therapeutic potential. Curr Opin Immunol 2007; 19: 488-496.

5. Claveria C, Giovinazzo G, Sierra R, Torres M. Myc-driven endogenous cell competition in the early mammalian embryo. Nature 2013; 500: 39-44.

6. Riether $\mathrm{C}$, Schurch $\mathrm{CM}$, Ochsenbein AF. Regulation of hematopoietic and leukemic stem cells by the immune system. Cell Death Differ 2014; 22: 187-198.

7. Vaux DL, Haecker G, Strasser A. An evolutionary perspective on apoptosis. Cell 1994; 76 : 777-779.

8. Strasser A. The role of BH3-only proteins in the immune system. Nat Rev Immunol 2005; 5 189-200.

9. Garg AD, Nowis D, Golab J, Vandenabeele P, Krysko DV, Agostinis P. Immunogenic cell death, DAMPs and anticancer therapeutics: an emerging amalgamation. Biochim Biophys Acta 2010; 1805: 53-71.

10. Vaux DL. Cell Death and Cancer. Cell Death 2014: 121-134.

11. Inoue H, Tani K. Multimodal immunogenic cancer cell death as a consequence of anticancer cytotoxic treatments. Cell Death Differ 2014; 21: 39-49.

12. Hotchkiss RS, Strasser A, McDunn JE, Swanson PE. Cell death. N Engl J Med 2009; 361: 1570-1583.

13. Golstein P. Cell death in us and others. Science (New York, NY) 1998; 281: 1283.

14. Yuan J, Kroemer G. Alternative cell death mechanisms in development and beyond. Genes Dev 2010; 24: 2592-2602.

15. Adams JM. Ways of dying: multiple pathways to apoptosis. Genes Dev 2003; 17: 2481-2495.

16. Shi Y. Mechanical aspects of apoptosome assembly. Curr Opin Cell Biol 2006; 18: 677-684.

17. Zamzami N, Kroemer G. The mitochondrion in apoptosis: how Pandora's box opens. Nat Rev Mol Cell Biol 2001; 2: 67-71.

18. Kluck RM, Bossy-Wetzel E, Green DR, Newmeyer DD. The release of cytochrome c from mitochondria: a primary site for Bcl-2 regulation of apoptosis. Science (New York, NY) 1997; 275: 1132-1136.

19. Zou H, Henzel WJ, Liu X, Lutschg A, Wang X. Apaf-1 a human protein homologous to C. elegans CED-4, participates in cytochrome c-dependent activation of caspase-3. Cell 1997; 90: 405-413.

20. Hassan M, Watari H, AbuAlmaaty A, Ohba Y, Sakuragi N. Apoptosis and molecular targeting therapy in cancer. Biomed Res Int 2014; 2014: 150845.

21. Kroemer G, Dallaporta B, Resche-Rigon M. The mitochondrial death/life regulator in apoptosis and necrosis. Annu Rev Physiol 1998; 60: 619-642.

22. Reed JC, Kromer G. Mitochondrial control of cell death. Nat Med 2000; 6: 513-519.

23. Lavrik IN, Eils R, Fricker N, Pforr C, Krammer PH. Understanding apoptosis by systems biology approaches. Mol Biosyst 2009; 5: 1105-1111.

24. Schleich K, Lavrik IN. Mathematical modeling of apoptosis. Cell Commun Signal 2013; 11: 44
25. Lavrik IN. Systems biology of apoptosis signaling networks. Curr Opin Biotechnol 2010; 21: 551-555.

26. Schleich K, Krammer PH, Lavrik IN. The chains of death: a new view on caspase-8 activation at the DISC. Cell Cycle (Georgetown, Tex) 2013; 12: 193-194.

27. Ravi R, Jain AJ, Schulick RD, Pham V, Prouser TS, Allen $\mathrm{H}$ et al. Elimination of hepatic metastases of colon cancer cells via p53-independent cross-talk between irinotecan and Apo2 ligand/TRAlL. Cancer Res 2004; 64: 9105-9114.

28. Kelley SK, Ashkenazi A. Targeting death receptors in cancer with Apo2L/TRAIL. Curr Opin Pharmacol 2004; 4: 333-339.

29. Ashkenazi A. Targeting death and decoy receptors of the tumour-necrosis factor superfamily. Nat Rev Cancer 2002; 2: 420-430.

30. Johnstone RW, Frew AJ, Smyth MJ. The TRAIL apoptotic pathway in cancer onset, progression and therapy. Nat Rev Cancer 2008; 8: 782-798.

31. Wilson NS, Dixit V, Ashkenazi A. Death receptor signal transducers: nodes of coordination in immune signaling networks. Nat Immunol 2009; 10: 348-355.

32. Kischkel F, Hellbardt S, Behrmann I, Germer M, Pawlita M, Krammer P et al. Cytotoxicitydependent APO-1 (Fas/CD95)-associated proteins form a death-inducing signaling complex (DISC) with the receptor. EMBO J 1995; 14: 5579.

33. Krammer PH, Arnold R, Lavrik IN. Life and death in peripheral T cells. Nat Rev Immunol 2007; 7: 532-542.

34. Lavrik I. Systems biology of death receptor networks: live and let die. Cell Death Dis 2013; 5: e1259.

35. Liu JJ, Lin M, Yu JY, Liu B, Bao JK. Targeting apoptotic and autophagic pathways for cancer therapeutics. Cancer Lett 2011; 300: 105-114.

36. Ubah OC, Wallace HM. Cancer therapy: targeting mitochondria and other sub-cellular organelles. Curr Pharmaceut Des 2014; 20: 201-222.

37. Evan Gl, Vousden KH. Proliferation, cell cycle and apoptosis in cancer. Nature 2001; 411: 342-348.

38. Liu J-j Lin M, Yu J-y, Liu B, Bao J-k. Targeting apoptotic and autophagic pathways for cancer therapeutics. Cancer Lett 2011; 300: 105-114.

39. Gautschi O, Tschopp S, Olie RA, Leech SH, Simões-Wüst AP, Ziegler A et al. Activity of a novel bcl-2/bcl-xL-bispecific antisense oligonucleotide against tumors of diverse histologic origins. J Natl Cancer Inst 2001; 93: 463-471.

40. Kang $\mathrm{MH}$, Reynolds $\mathrm{CP}$. Bcl-2 inhibitors: targeting mitochondrial apoptotic pathways in cancer therapy. Clin Cancer Res 2009; 15: 1126-1132.

41. Papadopoulos K. Targeting the Bcl-2 family in cancer therapy. Semin Oncol (Elsevier) 2006; 33: 449-456.

42. Thomas S, Quinn BA, Das SK, Dash R, Emdad L, Dasgupta S et al. Targeting the Bcl-2 family for cancer therapy. Expert Opin Ther Targets 2013; 17: 61-75.

43. Danial NN, Korsmeyer SJ. Cell death: critical control points. Cell 2004; 116: 205-219.

44. Willis SN, Adams JM. Life in the balance: how BH3-only proteins induce apoptosis. Curr Opin Cell Biol 2005; 17: 617-625.

45. Giam M, Huang D, Bouillet P. BH3-only proteins and their roles in programmed cell death. Oncogene 2008; 27: S128-S136.

46. Labi V, Erlacher M, Kiessling S, Villunger A. BH3-only proteins in cell death initiation, malignant disease and anticancer therapy. Cell Death Differ 2006; 13: $1325-1338$.

47. Letai A, Bassik MC, Walensky LD, Sorcinelli MD, Weiler S, Korsmeyer SJ. Distinct BH3 domains either sensitize or activate mitochondrial apoptosis, serving as prototype cancer therapeutics. Cancer Cell 2002; 2: 183-192.

48. Kuwana T, Bouchier-Hayes L, Chipuk JE, Bonzon C, Sullivan BA, Green DR et al. $\mathrm{BH} 3$ domains of BH3-only proteins differentially regulate Bax-mediated mitochondrial membrane permeabilization both directly and indirectly. Mol Cell 2005; 17: 525-535.

49. McDonnell TJ, Deane N, Platt FM, Nunez G, Jaeger U, McKearn JP et al. bcl-2-Immunoglobulin transgenic mice demonstrate extended B cell survival and follicular lymphoproliferation. Cell 1989; 57: 79-88.

50. Strasser A, Harris AW, Cory S. bcl-2 transgene inhibits T cell death and perturbs thymic self-censorship. Cell 1991; 67: 889-899.

51. Tsujimoto Y, Finger LR, Yunis J, Nowell PC, Croce CM. Cloning of the chromosome breakpoint of neoplastic B cells with the $t(14 ; 18)$ chromosome translocation. Science (New York, NY) 1984; 226: 1097-1099.

52. Willis SN, Chen L, Dewson G, Wei A, Naik E, Fletcher Jl et al. Proapoptotic Bak is sequestered by $\mathrm{Mcl}-1$ and $\mathrm{Bcl}-\mathrm{xL}$, but not $\mathrm{Bcl}-2$, until displaced by $\mathrm{BH} 3-o n l y$ proteins. Genes Dev 2005; 19: 1294-1305.

53. Dias N, Stein C. Antisense oligonucleotides: basic concepts and mechanisms. Mol Cancer Ther 2002; 1: 347-355.

54. Bacon TA, Morvan F, Rayner B, Imbach J-L, Wickstrom E. $\alpha$-Oligodeoxynucleotide stability in serum, subcellular extracts and culture media. J Biochem Biophys Methods 1988; 16: 311-318.

55. Wickstrom E. Oligodeoxynucleotide stability in subcellular extracts and culture media. J Biochem Biophys Methods 1986; 13: 97-102.

56. Akhtar S, Kole R, Juliano R. Stability of antisense DNA oligodeoxynucleotide analogs in cellular extracts and sera. Life Sci 1991; 49: 1793-1801.

57. Paula Simões-Wüst A, Hopkins-Donaldson S, Sigrist B, Belyanskaya L, Stahel RA, Zangemeister-Wittke U. A functionally improved locked nucleic acid antisense 
oligonucleotide inhibits $\mathrm{Bcl}-2$ and $\mathrm{Bcl}-\mathrm{xL}$ expression and facilitates tumor cell apoptosis. Oligonucleotides 2004; 14: 199-209.

58. Oltersdorf T, Elmore SW, Shoemaker AR, Armstrong RC, Augeri DJ, Belli BA et al. An inhibitor of Bcl-2 family proteins induces regression of solid tumours. Nature 2005; 435 : $677-681$.

59. Kamal A, Faazil S, Malik M S. Apoptosis-inducing agents: a patent review (2010-2013). Expert Opin Ther Patents 2014; 24: 339-354.

60. Rudin CM, Salgia R, Wang X, Hodgson LD, Masters GA, Green M et al. Randomized phase II study of carboplatin and etoposide with or without the bcl-2 antisense oligonucleotide oblimersen for extensive-stage small-cell lung cancer: CALGB 30103. J Clin Oncol 2008; 26: $870-876$

61. Marcucci G, Moser B, Blum W, Stock W, Wetzler M, Kolitz J. A phase III randomized trial of intensive induction and consolidation chemotherapy \pm oblimersen, a pro-apoptotic $\mathrm{Bcl}-2$ antisense oligonucleotide in untreated acute myeloid leukemia patients $>60$ years old. J Clin Oncol 2007; 25: 7012

62. Bedikian AY, Millward M, Pehamberger H, Conry R, Gore M, Trefzer U et al. Bcl-2 antisense (oblimersen sodium) plus dacarbazine in patients with advanced melanoma: the Oblimersen Melanoma Study Group. J Clin Oncol 2006; 24: 4738-4745.

63. Ozvaran MK, Cao XX, Miller SD, Monia BA, Hong WK, Smythe WR. Antisense oligonucleotides directed at the bcl-xl gene product augment chemotherapy response in mesothelioma. Mol Cancer Ther 2004; 3: 545-550.

64. Johnston JB, Paul JT, Neufeld NJ, Haney N, Kropp DM, Hu X et al. Role of myeloid cell factor-1 (Mcl-1) in chronic lymphocytic leukemia. Leuk Lymphoma 2004; 45 : 2017-2027

65. Allal AS, Waelchli L, Bründler M-A. Prognostic value of apoptosis-regulating protein expression in anal squamous cell carcinoma. Clin Cancer Res 2003; 9: 6489-6496.

66. Herbst RS, Frankel SR. Oblimersen sodium (Genasense bcl-2 antisense oligonucleotide): a rational therapeutic to enhance apoptosis in therapy of lung cancer. Clin Cancer Res 2004; 10: 4245s-4248s

67. Glozak M, Seto E. Histone deacetylases and cancer. Oncogene 2007; 26: 5420-5432.

68. Eot-Houllier G, Fulcrand G, Magnaghi-Jaulin L, Jaulin C. Histone deacetylase inhibitors and genomic instability. Cancer Lett 2009; 274: 169-176.

69. Hrabeta J, Stiborova M, Adam V, Kizek R, Eckschlager T. Histone deacetylase inhibitors in cancer therapy. A review. Biomed Pap 2014; 158: 161-169.

70. Becher I, Dittmann A, Savitski M M, Hopf C, Drewes G, Bantscheff M. Chemoproteomics reveals time-dependent binding of histone deacetylase inhibitors to endogenous repressor complexes. ACS Chem Biol 2014; 9: 1736-1746.

71. West AC, Johnstone RW. New and emerging HDAC inhibitors for cancer treatment. J Clin Invest 2014; 124: 30-39.

72. Bolden J E, Peart M J, Johnstone R W. Anticancer activities of histone deacetylase inhibitors. Nat Rev Drug Discov 2006; 5: 769-784.

73. Ellis L, Bots M, Lindemann R K, Bolden J E, Newbold A, Cluse L A et al. The histone deacetylase inhibitors LAQ824 and LBH589 do not require death receptor signaling or a functional apoptosome to mediate tumor cell death or therapeutic efficacy. Blood 2009; 114: 380-393

74. Momparler RL, Côté S, Momparler LF, Idaghdour Y. Epigenetic therapy of acute myeloid leukemia using 5-aza-2'-deoxycytidine (decitabine) in combination with inhibitors of histone methylation and deacetylation. Clin Epigenet 2015; 6: 19.

75. Li W, Gong X, Sun M, Zhao X, Gong B, Wei H et al. High-dose cytarabine in acute myeloid leukemia treatment: a systematic review and meta-analysis. PLOS ONE 2014; 9: e110153.

76. Grishina O, Schmoor C, Döhner K, Hackanson B, Lubrich B, May AM. DECIDER: prospective randomized multicenter phase II trial of low-dose decitabine (DAC) administered alone or in combination with the histone deacetylase inhibitor valproic acid (VPA) and all-trans retinoic acid (ATRA) in patients $>60$ years with acute myeloid leukemia who are ineligible for induction chemotherapy. BMC Cancer 2015; 15: 430.

77. Cea M, Cagnetta A, Gobbi M, Patrone F, Richardson PG, Hideshima T et al. New insights into the treatment of multiple myeloma with histone deacetylase inhibitors. Curr Pharmaceut Des 2013; 19: 734-744.

78. Piekarz RL, Frye R, Turner M, Wright JJ, Allen SL, Kirschbaum MH et al. Phase II multiinstitutional trial of the histone deacetylase inhibitor romidepsin as monotherapy for patients with cutaneous T-cell lymphoma. J Clin Oncol 2009; 27: 5410-5417.

79. Marks PA. The clinical development of histone deacetylase inhibitors as targeted anticancer drugs. Expert Opin Invest Drugs 2010; 19: 1049-1066.

80. Bai L, Wang S. Targeting apoptosis pathways for new cancer therapeutics. Annu Rev Med 2014; 65: 139-155.

81. Kögel D. Exploiting BH3 Mimetics for Cancer Therapy. Mitochondria: The Anti-cancer Target for the Third Millennium. Springer 2014; 39-58.

82. Lheureux S, N'Diaye M, Blanc-Fournier C, Dugué AE, Clarisse B, Dutoit $S$ et al. Identification of predictive factors of response to the BH3-mimetic molecule ABT-737: an ex vivo experiment in human serous ovarian carcinoma. Int $J$ Cancer 2015; 13 : E340-E350.

83. Llambi F, Moldoveanu T, Tait SW, Bouchier-Hayes L, Temirov J, McCormick LL et al. A unified model of mammalian BCL-2 protein family interactions at the mitochondria. Mol Cell 2011; 44: 517-531.
84. Mérino D, Giam M, Hughes PD, Siggs OM, Heger K, O'Reilly LA et al. The role of BH3-only protein Bim extends beyond inhibiting Bcl-2-like prosurvival proteins. J Cell Biol 2009; 186 355-362.

85. Gross A, McDonnell JM, Korsmeyer SJ. BCL-2 family members and the mitochondria in apoptosis. Genes Dev 1999; 13: 1899-1911.

86. Chen L, Willis SN, Wei A, Smith BJ, Fletcher JI, Hinds MG et al. Differential targeting of prosurvival $\mathrm{Bcl}-2$ proteins by their $\mathrm{BH} 3$-only ligands allows complementary apoptotic function. Mol Cell 2005; 17: 393-403.

87. Willis SN, Fletcher Jl, Kaufmann T, van Delft MF, Chen L, Czabotar PE et al. Apoptosis initiated when BH3 ligands engage multiple Bcl-2 homologs, not Bax or Bak. Science (New York, NY) 2007; 315: 856-859.

88. Certo M, Moore VDG, Nishino M, Wei G, Korsmeyer S, Armstrong SA et al. Mitochondria primed by death signals determine cellular addiction to antiapoptotic BCL-2 family members. Cancer Cell 2006; 9: 351-365.

89. Gavathiotis E, Suzuki M, Davis ML, Pitter K, Bird GH, Katz SG et al. BAX activation is initiated at a novel interaction site. Nature 2008; 455: 1076-1081.

90. Kim H, Rafiuddin-Shah M, Tu H-C, Jeffers JR, Zambetti GP, JJ-D Hsieh et al. Hierarchical regulation of mitochondrion-dependent apoptosis by BCL-2 subfamilies. Nat Cell Biol 2006; 8: $1348-1358$.

91. Lee M-S, Ha J-H, Yoon HS, Lee C-K, Chi S-W. Structural basis for the conserved binding mechanism of MDM2-inhibiting peptides and anti-apoptotic Bcl-2 family proteins. Biochem Biophys Res Commun 2014; 445: 120-125.

92. Lindqvist LM, Heinlein M, Huang DC, Vaux DL. Prosurvival Bcl-2 family members affect autophagy only indirectly by inhibiting Bax and Bak. Proc Natl Acad Sci 2014; 111 8512-7.

93. Liu Q, Chi X, Leber B, Andrews DW. Bcl-2 family and their therapeutic potential. In: WU H (ed) Cell Death. Springer: New York, NY, USA, 2014, pp 61-96.

94. Fairbrother WJ, Ashkenazi A. Designer proteins to trigger cell death. Cell 2014; 157 1506-1508.

95. Moldoveanu T, Follis AV, Kriwacki RW, Green DR. Many players in BCL-2 family affairs Trends Biochem Sci 2014; 39: 101-111.

96. Polier G, Giaisi M, Köhler R, Müller W W, Lutz C, Buss E C et al. Targeting CDK9 by wogonin and related natural flavones potentiates the anti-cancer efficacy of the Bcl-2 family inhibitor ABT-263. Int J Cancer 2015; 136: 688-698.

97. Renault TT, Elkholi R, Bharti A, Chipuk JE. BH3 mimetics demonstrate differential activities dependent upon the functional repertoire of pro-and anti-apoptotic BCL-2 family proteins. J Biol Chem 2014; M114: 569632.

98. Hassig C A, Zeng F Y, Kung P, Kiankarimi M, Kim S, Diaz P W et al. Ultra-high-throughput screening of natural product extracts to identify proapoptotic inhibitors of Bcl-2 family proteins. J Biomol Screen 2014; 19: 1201-1211.

99. Ryu Y, Hall CP, Reynolds CP, Kang MH. Caspase-dependent Mcl-1 cleavage and effect of Mcl-1 phosphorylation in ABT-737-induced apoptosis in human acute lymphoblastic leukemia cell lines. Exp Biol Med 2014; 239: 1390-1402.

100. Wroblewski D, Mijatov B, Mohana-Kumaran N, Lai F, Gallagher SJ, Haass NK et al. The BH3-mimetic ABT-737 sensitizes human melanoma cells to apoptosis induced by selective BRAF inhibitors but does not reverse acquired resistance. Carcinogenesis 2013; 34: 237-247.

101. LaCasse E, Mahoney D, Cheung H, Plenchette S, Baird S, Korneluk R. IAP-targeted therapies for cancer. Oncogene 2008; 27: 6252-6275.

102. Bunz F, Hwang PM, Torrance $C$, Waldman $T$, Zhang $Y$, Dillehay L et al. Disruption of $p 53$ in human cancer cells alters the responses to therapeutic agents. J Clin Invest 1999; 104: 263-269.

103. Rustum YM. Thymidylate synthase: a critical target in cancer therapy? Front Biosci 2004; 9: 2467-2473

104. Schultz R, Patel V, Worzalla J, Shih C. Role of thymidylate synthase in the antitumor activity of the multitargeted antifolate, LY231514. Anticancer Res 1998; 19: 437-443.

105. Khan KH, Blanco-Codesido M, Molife L. Cancer therapeutics: targeting the apoptotic pathway. Crit Rev Oncol/Hematol 2014; 90: 200-219.

106. Deveraux QL, Takahashi R, Salvesen GS, Reed JC, X-linked IAP. is a direct inhibitor of celldeath proteases. Nature 1997; 388: 300-304.

107. Deveraux QL, Roy N, Stennicke HR, Van Arsdale T, Zhou Q, Srinivasula SM et al. IAPs block apoptotic events induced by caspase-8 and cytochrome $c$ by direct inhibition of distinct caspases. EMBO J 1998; 17: 2215-2223.

108. LaCasse EC, Mahoney DJ, Cheung HH, Plenchette S, Baird S, Korneluk RG. IAP-targeted therapies for cancer. Oncogene 2008; 27: 6252-6275.

109. Lemke J, von Karstedt S, Zinngrebe J, Walczak H. Getting TRAlL back on track for cancer therapy. Cell Death Differ 2014; 21: 1350-1364.

110. Ramp U, Krieg T, Caliskan E, Mahotka C, Ebert T, Willers R et al. XIAP expression is an independent prognostic marker in clear-cell renal carcinomas. Hum Pathol 2004; 35 1022-1028.

111. Ferreira CG, van der Valk P, Span SW, Jonker JM, Postmus PE, Kruyt FA et al. Assessment of IAP (inhibitor of apoptosis) proteins as predictors of response to chemotherapy in advanced non-small-cell lung cancer patients. Ann Oncol 2001a; 12: 799-805.

112. Ferreira CG, van der Valk $P$, Span SW, Ludwig I, Smit EF, Kruyt FA. Expression of X-linked inhibitor of apoptosis as a novel prognostic marker in radically resected non-small cell lung cancer patients. Clin Cancer Res 2001b; 7: 2468-2474. 
113. Liu S, Tsang BK, Cheung AN, Xue WC, Cheng DK, Ng TY. Anti-apoptotic proteins, apoptotic and proliferative parameters and their prognostic significance in cervical carcinoma. Eur J Cancer 2001; 37: 1104-1110.

114. Mao HL, Liu PS, Zheng JF, Zhang PH, Zhou LG, Xin G et al. Transfection of Smac/DIABLO sensitizes drug-resistant tumor cells to TRAIL or paclitaxel-induced apoptosis in vitro Pharmacol Res 2007; 56: 483-492.

115. Varambally S, Yu J, Laxman B, Rhodes DR, Mehra R, Tomlins SA et al. Integrative genomic and proteomic analysis of prostate cancer reveals signatures of metastatic progression. Cancer Cell 2005; 8: 393-406.

116. Mannhold R, Fulda S, Carosati E. IAP antagonists: promising candidates for cancer therapy. Drug Discov Today 2010; 15: 210-219.

117. Lavrik IN. Systems biology of death receptor networks: live and let die. Cell Death Dis 2014; 5: e1259.

118. Ashkenazi A, Pai RC, Fong S, Leung S, Lawrence DA, Marsters SA et al. Safety and antitumor activity of recombinant soluble Apo2 ligand. J Clin Invest 1999; 104: 155-162.

119. LeBlanc $\mathrm{H}$, Ashkenazi A. Apo2L/TRAIL and its death and decoy receptors. Cell Death Differ 2003; 10: 66-75.

120. Sheridan JP, Marsters SA, Pitti RM, Gurney A, Skubatch M, Baldwin D et al. Control of TRAIL-induced apoptosis by a family of signaling and decoy receptors. Science 1997; 277: 818-821.

121. Ichikawa K, Liu W, Zhao L, Wang Z, Liu D, Ohtsuka T et al. Tumoricidal activity of a novel anti-human DR5 monoclonal antibody without hepatocyte cytotoxicity. Nat Med 2001; 7 : 954-960.

122. Dimberg L, Anderson C, Camidge R, Behbakht K, Thorburn A, Ford H. On the TRAIL to successful cancer therapy? Predicting and counteracting resistance against TRAIL-based therapeutics. Oncogene 2012; 32: 1341-1350.

123. Nebbioso A, Carafa V, Benedetti R, Altucci L. Trials with 'epigenetic'drugs: an update. Mol Oncol 2012; 6: 657-682.

124. Qiu T, Zhou L, Zhu W, Wang T, Wang J, Shu $Y$ et al. Effects of treatment with histone deacetylase inhibitors in solid tumors: a review based on 30 clinical trials. Future Oncol 2013; 9: 255-269.

125. Falkenberg $\mathrm{K} \mathrm{J}$, Johnstone $\mathrm{R} \mathrm{W}$. Histone deacetylases and their inhibitors in cancer, neurological diseases and immune disorders. Nat Rev Drug Disc 2014; 13: 673-691.

126. Badros A, Burger A M, Philip S, Niesvizky R, Kolla S S, Goloubeva O et al. Phase I study of vorinostat in combination with bortezomib for relapsed and refractory multiple myeloma. Clin Cancer Res 2009; 15: 5250-5257.

127. Weber D M, Graef T, Hussein M, Sobecks R M, Schiller G J, Lupinacci L et al. Phase I trial of vorinostat combined with bortezomib for the treatment of relapsing and/or refractory multiple myeloma. Clin Lymphoma Myeloma Leuk 2012; 12: 319-324.

128. Mottamal M, Zheng S, Huang T L, Wang G. Histone deacetylase inhibitors in clinical studies as templates for new anticancer agents. Molecules 2015; 20: 3898-3941.

129. Brinkmann K, Kashkar H. Targeting the mitochondrial apoptotic pathway: a preferred approach in hematologic malignancies? Cell Death Dis 2014; 5: e1098.

130. Pro B, Leber B, Smith M, Fayad L, Romaguera J, Hagemeister F et al. Phase II multicenter study of oblimersen sodium, a Bcl-2 antisense oligonucleotide, in combination with rituximab in patients with recurrent B-cell non-Hodgkin lymphoma. Br J Haematol 2008; 143: $355-360$.

131. Chi KN, Gleave ME, Klasa R, Murray N, Bryce C, Lopes de Menezes DE et al. A phase I dose-finding study of combined treatment with an antisense Bcl-2 oligonucleotide (Genasense) and mitoxantrone in patients with metastatic hormone-refractory prostate cancer. Clin Cancer Res 2001; 7: 3920-3927.

132. Tolcher AW, Chi K, Kuhn J, Gleave M, Patnaik A, Takimoto C et al. A phase II, pharmacokinetic, and biological correlative study of oblimersen sodium and docetaxel in patients with hormone-refractory prostate cancer. Clin Cancer Res 2005; 11: 3854-3861.

133. Marshall J, Chen H, Yang D, Figueira M, Bouker KB, Ling Y et al. A phase I trial of a Bcl-2 antisense (G3139) and weekly docetaxel in patients with advanced breast cancer and other solid tumors. Ann Oncol 2004; 15: 1274-1283.

134. Marcucci G, Stock W, Dai G, Klisovic RB, Liu S, Klisovic Ml et al. Phase I study of oblimersen sodium, an antisense to $\mathrm{Bcl}-2$, in untreated older patients with acute myeloid leukemia: Pharmacokinetics, pharmacodynamics, and clinical activity. J Clin Oncol 2005; 23: 3404-3411.

135. Rudin CM, Kozloff M, Hoffman PC, Edelman MJ, Karnauskas R, Tomek R et al. Phase I study of G3139, a bcl-2 antisense oligonucleotide, combined with carboplatin and etoposide in patients with small-cell lung cancer. J Clin Oncol 2004; 22: 1110-1117.

136. Chanan-Khan AA, Niesvizky R, Hohl RJ, Zimmerman TM, Christiansen NP, Schiller GJ et al. Phase III randomised study of dexamethasone with or without oblimersen sodium for patients with advanced multiple myeloma. Leuk Lymphoma 2009; 50: 559-565.

137. O'Brien SM, Claxton DF, Crump M, Faderl S, Kipps T, Keating MJ et al. Phase I study of obatoclax mesylate (GX15-070), a small molecule pan-Bcl-2 family antagonist, in patients with advanced chronic lymphocytic leukemia. Blood 2009; 113: 299-305.

138. Moore J, Seiter K, Kolitz J, Stock W, Giles F, Kalaycio M et al. A phase II study of Bcl-2 antisense (oblimersen sodium) combined with gemtuzumab ozogamicin in older patients with acute myeloid leukemia in first relapse. Leuk Res 2006; 30: 777-783.

139. Paik PK, Rudin CM, Pietanza MC, Brown A, Rizvi NA, Takebe N et al. A phase II study of obatoclax mesylate, a Bcl-2 antagonist, plus topotecan in relapsed small cell lung cancer. Lung Cancer (Amsterdam, Netherlands) 2011; 74: 481-485.
140. Parikh SA, Kantarjian H, Schimmer A, Walsh W, Asatiani E, El-Shami K et al. Phase II study of obatoclax mesylate (GX15-070), a small-molecule BCL-2 family antagonist, for patients with myelofibrosis. Clin Lymphoma myeloma Leuk 2010; 10: 285-289.

141. Liu G, Kelly WK, Wilding G, Leopold L, Brill K, Somer B. An open-label, multicenter, phase $\mathrm{I} / \mathrm{I}$ study of single-agent AT-101 in men with castrate-resistant prostate cancer. Clin Cancer Res 2009; 15: 3172-3176.

142. Sonpavde G, Matveev V, Burke JM, Caton JR, Fleming MT, Hutson TE et al. Randomized phase II trial of docetaxel plus prednisone in combination with placebo or AT-101, an oral small molecule Bcl-2 family antagonist, as first-line therapy for metastatic castrationresistant prostate cancer. Ann Oncol 2012; 23: 1803-1808.

143. Van Poznak C, Seidman AD, Reidenberg MM, Moasser MM, Sklarin N, Van Zee K et al. Oral gossypol in the treatment of patients with refractory metastatic breast cancer: a phase I/II clinical trial. Breast Cancer Res Treat 2001; 66: 239-248.

144. Wilson WH, O'Connor OA, Czuczman MS, LaCasce AS, Gerecitano JF, Leonard JP et al. Navitoclax, a targeted high-affinity inhibitor of BCL-2, in lymphoid malignancies: a phase 1 dose-escalation study of safety, pharmacokinetics, pharmacodynamics, and antitumour activity. The Lancet Oncol 2010; 11: 1149-1159.

145. Roberts AW, Seymour JF, Brown JR, Wierda WG, Kipps TJ, Khaw SL et al. Substantial susceptibility of chronic lymphocytic leukemia to BCL2 inhibition: results of a phase I study of navitoclax in patients with relapsed or refractory disease. J Clin Oncol 2012; 30: 488-496.

146. Dai Y, Liu M, Tang W, DeSano J, Burstein E, Davis M et al. Molecularly targeted radiosensitization of human prostate cancer by modulating inhibitor of apoptosis. Clin Cancer Res 2008; 14: 7701-7710.

147. Dineen SP, Roland CL, Greer R, Carbon JG, Toombs JE, Gupta P et al. Smac mimetic increases chemotherapy response and improves survival in mice with pancreatic cancer. Cancer Res 2010; 70: 2852-2861.

148. Dai Y, Liu M, Tang W, Li Y, Lian J, Lawrence TS et al. A Smac-mimetic sensitizes prostate cancer cells to TRAIL-induced apoptosis via modulating both IAPs and NF-kappaB. BMC Cancer 2009; 9: 392.

149. Dean E, Jodrell D, Connolly K, Danson S, Jolivet J, Durkin J et al. Phase I trial of AEG35156 administered as a 7-day and 3-day continuous intravenous infusion in patients with advanced refractory cancer. J Clin Oncol 2009; 27: 1660-1666.

150. Tolcher AW, Mita A, Lewis LD, Garrett CR, Till E, Daud Al et al. Phase I and pharmacokinetic study of YM155, a small-molecule inhibitor of survivin. J Clin Oncol 2008; 26: 5198-5203.

151. Satoh T, Okamoto I, Miyazaki M, Morinaga R, Tsuya A, Hasegawa Y et al. Phase I study of YM155, a novel survivin suppressant, in patients with advanced solid tumors. Clin Cancer Res 2009; 15: 3872-3880.

152. Rödel F, Frey B, Leitmann W, Capalbo G, Weiss C, Rödel C. Survivin antisense oligonucleotides effectively radiosensitize colorectal cancer cells in both tissue culture and murine xenograft models. Int J Radiat Oncol Biol Phys 2008; 71: 247-255.

153. Yee L, Burris H, Kozloff M, Wainberg Z, Pao M, Skettino S. Phase lb study of recombinant human Apo2L/TRAIL plus irinotecan and cetuximab or FOLFIRI in metastatic colorectal cancer (mCRC) patients (pts): preliminary results. J Clin Oncol 2009; 27: 4129.

154. Soria J-C, Márk Z, Zatloukal P, Szima B, Albert I, Juhász E et al. Randomized phase II study of dulanermin in combination with paclitaxel, carboplatin, and bevacizumab in advanced non-small-cell lung cancer. J Clin Oncol 2011; 37: 623.

155. Hotte SJ, Hirte HW, Chen EX, Siu LL, Le LH, Corey A et al. A phase 1 study of mapatumumab (fully human monoclonal antibody to TRAIL-R1) in patients with advanced solid malignancies. Clin Cancer Res 2008; 14: 3450-3455.

156. Greco FA, Bonomi P, Crawford J, Kelly K, Oh Y, Halpern W et al. Phase 2 study of mapatumumab, a fully human agonistic monoclonal antibody which targets and activates the TRAIL receptor-1, in patients with advanced non-small cell lung cancer. Lung Cancer 2008; 61: 82-90.

157. Trarbach T, Moehler M, Heinemann V, Köhne C, Przyborek M, Schulz C et al. Phase II trial of mapatumumab, a fully human agonistic monoclonal antibody that targets and activates the tumour necrosis factor apoptosis-inducing ligand receptor-1 (TRAIL-R1), in patients with refractory colorectal cancer. Br J Cancer 2010; 102 : 506-512.

158. Saleh M, Percent I, Wood T, Posey J, Shah J, Carlisle R et al. A phase I study of CS-1008 (humanized monoclonal antibody targeting death receptor 5 or DR5), administered weekly to patients with advanced solid tumors or lymphomas. J Clin Oncol 2008; 26: 3537.

159. Camidge DR. Apomab: an agonist monoclonal antibody directed against Death Receptor 5/TRAIL-Receptor 2 for use in the treatment of solid tumors. Expert Opin Biol Ther 2008: 1167-1176.

160. Wakelee H, Patnaik A, Sikic B, Mita M, Fox N, Miceli R et al. Phase I and pharmacokinetic study of lexatumumab (HGS-ETR2) given every 2 weeks in patients with advanced solid tumors. Ann Oncol 2010; 21: 376-381.

161. Pacey S, Plummer R, Attard G, Bale C, Calvert A, Blagden S et al. Phase I and pharmacokinetic study of HGS-ETR2, a human monoclonal antibody to TRAIL R2, in patients with advanced solid malignancies. J Clin Oncol 2005; 23: 3055.

162. LoRusso P, Hong D, Heath E, Kurzrock R, Wang D, Hsu M et al. First-in-human study of AMG 655, a pro-apoptotic TRAIL receptor-2 agonist, in adult patients with advanced solid tumors. J Clin Oncol 2007; 25: 3534. 
163. Herbst RS, Kurzrock R, Hong DS, Valdivieso M, Hsu C-P, Goyal L et al. A first-in-human study of conatumumab in adult patients with advanced solid tumors. Clin Cancer Res 2010; 16: $5883-5891$.

164. Banerji U, van Doorn L, Papadatos-Pastos D, Kristeleit R, Debnam P, Tall M et al. A phase I pharmacokinetic and pharmacodynamic study of CHR-3996, an oral class I selective histone deacetylase inhibitor in refractory solid tumors. Clin Cancer Res 2012; 18: 2687-2694.

165. Kirschbaum MH, Foon KA, Frankel P, Ruel C, Pulone B, Tuscano JM et al. A phase 2 study of belinostat (PXD101) in patients with relapsed or refractory acute myeloid leukemia or patients over the age of 60 with newly diagnosed acute myeloid leukemia: a California Cancer Consortium Study. Leuk Lymphoma 2014: 1-4.

166. Zorzi AP, Bernstein M, Samson Y, Wall DA, Desai S, Nicksy D et al. A phase I study of histone deacetylase inhibitor, pracinostat (SB939), in pediatric patients with refractory solid tumors: IND203 a trial of the NCIC IND program/C17 pediatric phase I consortium. Pediatr Blood Cancer 2013; 60: 1868-1874.

167. Gray JE, Haura E, Chiappori A, Tanvetyanon T, Williams CC, Pinder-Schenck M et al. A phase I, pharmacokinetic, and pharmacodynamic study of Panobinostat, an HDAC inhibitor, combined with Erlotinib in patients with advanced aerodigestive tract tumors. Clin Cancer Res 2014; 20: 1644-1655.

168. Pili R, Salumbides B, Zhao M, Altiok S, Qian D, Zwiebel J et al. Phase I study of the histone deacetylase inhibitor entinostat in combination with 13-cis retinoic acid in patients with solid tumours. Br J Cancer 2011; 106: 77-84.

169. Dong M, Ning ZQ, Xing PY, Xu JL, Cao HX, Dou GF et al. Phase I study of chidamide (CS055/HBI-8000), a new histone deacetylase inhibitor, in patients with advanced solid tumors and lymphomas. Cancer Chemother Pharmacol 2012; 69: 1413-1422.

170. Galli M, Salmoiraghi S, Golay J, Gozzini A, Crippa C, Pescosta N et al. A phase II multiple dose clinical trial of histone deacetylase inhibitor ITF2357 in patients with relapsed or progressive multiple myeloma. Ann Hematol 2010; 89: 185-190.

171. Venugopal B, Baird R, Kristeleit RS, Plummer R, Cowan R, Stewart A et al. A phase I study of quisinostat (JNJ-26481585), an oral hydroxamate histone deacetylase inhibitor with evidence of target modulation and antitumor activity, in patients with advanced solid tumors. Clin Cancer Res 2013; 19: 4262-4272.

172. Younes A, Sureda A, Ben-Yehuda D, Zinzani PL, Ong T-C, Prince HM et al. Panobinostat in patients with relapsed/refractory Hodgkin's lymphoma after autologous stem-cell transplantation: results of a phase II study. J Clin Oncol 2012; 30: 2197-2203.

173. Fukutomi A, Hatake K, Matsui K, Sakajiri S, Hirashima T, Tanii $\mathrm{H}$ et al. A phase I study of oral panobinostat (LBH589) in Japanese patients with advanced solid tumors. Invest New Drugs 2012; 30: 1096-1106.

174. Berenson JR, Hilger JD, Yellin O, Boccia RV, Matous J, Dressler K et al. A phase 1/2 study of oral panobinostat combined with melphalan for patients with relapsed or refractory multiple myeloma. Ann Hematol 2014; 93: 89-98.

175. Bauer S, Hilger RA, Muhlenberg T, Grabellus F, Nagarajah J, Hoiczyk M et al. Phase study of panobinostat and imatinib in patients with treatment-refractory metastatic gastrointestinal stromal tumors. Br J Cancer 2014; 110: 1155-1162.

176. Pepper C, Lin TT, Pratt G, Hewamana S, Brennan P, Hiller L et al. Mcl-1 expression has in vitro and in vivo significance in chronic lymphocytic leukemia and is associated with other poor prognostic markers. Blood 2008; 112: 3807-3817.

177. Zhang B, Gojo I, Fenton RG. Myeloid cell factor-1 is a critical survival factor for multiple myeloma. Blood 2002; 99: 1885-1893.

178. Zhou P, Qian L, Kozopas KM, Craig RW. Mcl-1 a Bcl-2 family member, delays the death of hematopoietic cells under a variety of apoptosis-inducing conditions. Blood 1997; 89: 630-643.

179. Tamm I, Kornblau SM, Segall H, Krajewski S, Welsh K, Kitada S et al. Expression and prognostic significance of IAP-family genes in human cancers and myeloid leukemias. Clin Cancer Res 2000; 6: 1796-1803.

Cell Death and Disease is an open-access journal published by Nature Publishing Group. This work is licensed under a Creative Commons Attribution 4.0 International License. The images or other third party material in this article are included in the article's Creative Commons license, unless indicated otherwise in the credit line; if the material is not included under the Creative Commons license, users will need to obtain permission from the license holder to reproduce the material. To view a copy of this license, visit http://creativecommons.org/licenses/by/4.0/ 